\title{
Down-regulation of 1D-myo-inositol 1,4,5-trisphosphate 3-kinase A protein expression in oral squamous cell carcinoma
}

\author{
HISASHI KATO $^{1}$, KATSUHIRO UZAWA ${ }^{1,2}$, TAKESHI ONDA ${ }^{4}$, YOSHIKUNI KATO ${ }^{1}$, \\ KENGO SAITO $^{1}$, DAI NAKASHIMA ${ }^{1}$, KASTUNORI OGAWARA ${ }^{1,2}$, HIROKI BUKAWA ${ }^{2}$, \\ HIDETAKE YOKOE $^{2}$ and HIDEKI TANZAWA ${ }^{1-3}$ \\ ${ }^{1}$ Department of Clinical Molecular Biology, Graduate School of Medicine, Chiba University; ${ }^{2}$ Division of \\ Dentistry and Oral-Maxillofacial Surgery, Chiba University Hospital; ${ }^{3}$ Center of Excellence (COE) \\ Program in the 21st Century, Graduate School of Medicine, Chiba University, Chiba 260-8670; \\ ${ }^{4}$ First Department of Oral and Maxillo-Facial Surgery, Tokyo Dental College, Chiba 261-8502, Japan
}

Received November 14, 2005; Accepted December 22, 2005

\begin{abstract}
Functional proteomics is a useful method to explore changes in protein expression in human diseases, including carcinomas. To identify tumor-associated proteins as biomarkers or molecular targets of human oral squamous cell carcinomas (OSCCs), we performed two-dimensional polyacrylamide gel electrophoresis and matrix-assisted laser desorption/ionization-time of flight mass spectrometry. Comparison of the protein expression profiles of OSCC cell lines and normal oral keratinocytes identified six proteins with markedly different expression levels. Of the six proteins, we found a 1D-myo-inositol 1,4,5-trisphosphate 3-kinase A
\end{abstract}

Correspondence to: Dr Katsuhiro Uzawa, Department of Clinical Molecular Biology, Graduate School of Medicine, Chiba University, 1-8-1 Inohana, Chuo-ku, Chiba 260-8670, Japan

E-mail: uzawak@faculty.chiba-u.jp

Abbreviations: 2D-PAGE, two-dimensional polyacrylamide gel electrophoresis; MALDI-TOF-mass, matrix-assisted laser desorption/ ionization-time of flight mass spectrometry; OSCCs, oral squamous cell carcinomas; NOKs, normal oral keratinocytes; ITPKA, 1Dmyo-inositol 1,4,5-trisphosphate 3-kinase A; RT-PCR, reverse transcriptase-polymerase chain reaction; IHC, immunohistochemistry; Ins $(1,4,5) \mathrm{P}_{3}$, inositol 1,4,5-trisphosphate; $\mathrm{Ca}^{2+}$, calcium; DAG, 1,2-diacylglycerol; GTP, guanosine triphosphate; ER, endoplasmic reticulum; Ins $(1,4) \mathrm{P}_{2}$, inositol 1,4-bisphosphate; IPK3, inositol 1,4,5-trisphosphate 3-kinase; Ins $(1,3,4,5) \mathrm{P}_{4}$, inositol 1,3,4,5-tetrakisphosphate; ATP2C1, ATPase, $\mathrm{Ca}^{2+}$ transporting, type $2 \mathrm{C}$, member 1; ATP2A2, sarcoendoplasmic reticulum $\mathrm{Ca}^{2+}$ ATPase type 2; SCCs, squamous cell carcinomas; PMF, peptidemass fingerprinting; PBS, phosphate-buffered saline; OPLs, oral premalignant lesions; LOH, loss of heterozygosity; GAPDH, glyceraldehyde-3-phosphate dehydrogenase

Key words: ITPKA, oral squamous cell carcinoma, two-dimensional electrophoresis, MALDI-TOF-mass spectrometry, calcium signal transduction, inositol polyphosphates
(ITPKA) protein that was down-regulated in OSCC cell lines. ITPKA phosphorylates inositol 1,4,5-trisphosphate, which regulates the calcium $\left(\mathrm{Ca}^{2+}\right)$ level within the cell by releasing $\mathrm{Ca}^{2+}$ from intracellular stores, and is responsible for regulating the levels of a large number of inositol polyphosphates that are important in cellular signaling. Western blots revealed dramatically down-regulated ITPKA expression in all OSCC cell lines examined. Real-time quantitative reverse transcriptase-polymerase chain reaction showed down-regulated ITPKA mRNA expression in nine of $12(75 \%)$ OSCC cell lines. Immunohistochemistry analysis showed that 40 of 100 OSCC clinical samples had a significant decrease in ITPKA. Poorly differentiated tumors showed significantly lower immunoreactivity of the protein compared to well- and moderately-differentiated tumors. These data suggest that ITPKA may be related to carcinogenesis by the modulation of inositol polyphosphates and $\mathrm{Ca}^{2+}$ homeostasis and that ITPKA may be a potential novel molecular target, biomarker, parameter, or all of these of cellular differentiation and of intracellular $\mathrm{Ca}^{2+}$ homeostatic characteristics in clinical medicine.

\section{Introduction}

Biological responses consist of protein components resulting from transcriptional control, post-transcriptional regulation, and post-translational modifications. Thus, proteome analysis can provide important information in the study of the biological sciences. To identify the proteins associated with the development of human oral squamous cell carcinoma (OSCC), we compared the protein expression of OSCC cell lines with normal oral keratinocytes (NOKs), using two-dimensional polyacrylamide gel electrophoresis (2D-PAGE) and matrixassisted laser desorption/ionization-time of flight mass spectrometry (MALDI-TOF-mass). We found that 1D-myo-inositol 1,4,5-trisphosphate 3-kinase A protein (ITPKA) has markedly decreased expression in OSCC cell lines. To our knowledge, ITPKA has not been reported in oncogenesis. ITPKA phosphorylates inositol 1,4,5-trisphosphate $\left(\operatorname{Ins}(1,4,5) \mathrm{P}_{3}\right)$, which regulates intracellular calcium $\left(\mathrm{Ca}^{2+}\right)$ homeostasis (1-3). 
$\mathrm{Ca}^{2+}$ is a ubiquitous intracellular signal responsible for controlling numerous cellular processes, including fertilization, cell growth, transformation, secretion, smooth muscle contraction, sensory perception, and neuronal signaling $(4,5)$. Intracellular $\mathrm{Ca}^{2+}$ levels are buffered to a low concentration (100 $\mathrm{nM}$ ) and rapidly rise to $1 \mu \mathrm{M}$ or more in response to incoming signals (6). A second messenger, $\operatorname{Ins}(1,4,5) \mathrm{P}_{3}$, is part of various internal $\mathrm{Ca}^{2+}$ signals that regulate many different cellular functions (7). When the extracellular agonists, such as hormones and neurotransmitters, occupy a cell surface receptor, phosphatidylinositol 4,5-bis-phosphate in plasma membranes is hydrolyzed to $\operatorname{Ins}(1,4,5) \mathrm{P}_{3}$ and 1,2-diacylglycerol (DAG) by phospholipase $\mathrm{C}$ activity that is enhanced by guanosine triphosphate (GTP). The primary function of Ins $(1,4,5) \mathrm{P}_{3}$ is to mobilize $\mathrm{Ca}^{2+}$ from intracellular stores, probably in the endoplasmic reticulum, by binding to Ins $(1,4,5) \mathrm{P}_{3}$ receptors, whereas DAG is a direct activator of protein kinase $C(1-3,8-12)$. This bifurcating messenger system operates throughout the life of a typical cell in a variety of specialized cells in animals and plants (7). The levels of Ins $(1,4,5) \mathrm{P}_{3}$ are tightly regulated and rapidly metabolized by two mechanisms: dephosphorylation via an $\operatorname{Ins}(1,4,5) \mathrm{P}_{3} 5$ phosphatase to inositol 1,4-bisphosphate $\left(\operatorname{Ins}(1,4) \mathrm{P}_{2}\right)$ or phosphorylation via an inositol 1,4,5-trisphosphate 3-kinase (IPK3) to inositol 1,3,4,5-tetrakisphosphate $\left(\operatorname{Ins}(1,3,4,5) \mathrm{P}_{4}\right)$ (3). Human IPK3 exists as three isoforms, ITPKA, B, and C, of which ITPKA is the most highly characterized isoform and is expressed intensely in rat brain and testes $(3,13-15)$. ITPKA protein encoded by the gene located on chromosome $15 \mathrm{q} 14-\mathrm{q} 21$ is approximately $51 \mathrm{kDa}$ and consists of 461 amino acids. IPK3 activity is stimulated in the presence of $\mathrm{Ca}^{2+} /$ calmodulin via phosphorylation by cyclic AMP-dependent protein kinase, protein kinase $\mathrm{C}$, or $\mathrm{Ca}^{2+} /$ calmodulin-dependent protein kinase II $(3,14,16-18)$.

It is well known that impaired intracellular $\mathrm{Ca}^{2+}$ homeostasis, which ITPKA partly regulates, causes epithelial disorders. For instance, mutations in ATP2C1 (SPCA1), encoding a $\mathrm{Ca}^{2+}$ pump ( $\mathrm{Ca}^{2+}$-transport ATPase), cause HaileyHailey disease, which is an autosomal dominant disorder characterized by persistent blisters and erosions of the skin with impaired adhesion of keratinocytes $(19,20)$. In addition, mutations in ATP2A2 (SERCA2), encoding a $\mathrm{Ca}^{2+}$ pump $\left(\mathrm{Ca}^{2+}\right.$-transport ATPase) located in the scarcoendoplasmic reticulum (ER) and sequestering $\mathrm{Ca}^{2+}$ from the cytosol into the ER, cause Darier-White disease, an autosomal dominant disorder characterized by loss of adhesion in epidermal cells and abnormal keratinization (21-23). Mice with a SERCA2 heterozygous mutant have a high rate of spontaneously developing SCCs and premalignant lesions in keratinized epithelial cells of the upper digestive organs, including the oral cavity $(24,25)$. Endo et al showed that ATP2A2 is downregulated in human OSSCs (26). Furthermore, IgG from pemphigus, characterized by blister formation on the skin, causes a transient increase in the intracellular $\mathrm{Ca}^{2+}$ by Ins $(1,4,5) \mathrm{P}_{3}$ (27). Based on this evidence, we can presume that ITPKA is related to intracellular $\mathrm{Ca}^{2+}$ homeostasis and also causes epithelial disorders, including OSCCs.

To verify the result of proteome analysis using 2D-PAGE and MALDI-TOF-mass and to investigate the contribution of changes in ITPKA to carcinogenesis in the oral squamous epithelium, we also analyzed the mRNA and protein levels in OSCC cell lines and NOKs and expression levels in immunohistochemistry (IHC) of OSCC clinical samples.

\section{Materials and methods}

Cell cultures. We used the human OSCC cell lines HSC-2, HSC-3, HSC-4, Ho-1-N-1, Ca9-22, SKN3, Kosc2, KON, SAT, SAS (Human Science Research Resources Bank, Osaka, Japan), OK92 (established from carcinoma of the tongue in our department), and Sa3 and H1 (kindly provided by Dr Fujita at Wakayama Medical University, Wakayama, Japan). All cell lines were maintained at $37^{\circ} \mathrm{C}$ (humidified atmosphere $5 \% \mathrm{CO}_{2} / 95 \%$ air) on $150 \times 20-\mathrm{mm}$ tissue culture dishes (Nunc, Roskilde, Denmark) and cultured in Dulbecco's modified Eagle's medium F-12 HAM (Sigma Chemical Co., St. Louis, MO) with $10 \%$ fetal bovine serum (Sigma) and 50 units $/ \mathrm{ml}$ penicillin and streptomycin.

Five NOK strains from five patients who had undergone dental surgery served as the controls in the experimental procedures. All patients provided written informed consent before the start of the study. The normal oral specimens were washed in Dulbecco's phosphate-buffered saline (PBS) (Sigma) and then placed overnight in $0.25 \%$ trypsin-EDTA solution (Sigma) at $4^{\circ} \mathrm{C}$. After the epithelial tissue separated from the connective tissue, it was disaggregated by incubation in $0.25 \%$ trypsin-EDTA solution for 15 min with gentle pipetting at $37^{\circ} \mathrm{C}$. Isolated epithelial cells then were seeded into Collagen I Cellware 60-mm dish biocoat cell environments (BectonDickinson Labware, Bedford, MA) and cultured in Keratinocyte Basal Medium-2 (Cambrex, Walkersville, MD) with $0.4 \%$ bovine pituitary extract, $0.1 \%$ human epidermal growth factor, $0.1 \%$ insulin, $0.1 \%$ hydrocortisone, $0.1 \%$ transferrin, $0.1 \%$ epinephrine, and $0.1 \%$ GA-1000 (Cambrex).

Tissue samples for IHC. Tumors or oral leukoplakias with patient-matched normal oral tissue were obtained at the time of surgery at Chiba University Hospital after informed consent was obtained from the patients, according to a protocol that was reviewed and approved by the institutional review board of Chiba University. The resected tissue was fixed in $10 \%$ buffered formaldehyde solution for pathological diagnosis and IHC staining. Histopathological diagnosis of each cancerous tissue was performed according to the International Histological Classification of Tumours by the Department of Pathology, Chiba University Hospital. Clinicopathological staging was determined by the TNM classification of the International Union against Cancer. All patients had histologically-confirmed SCC.

2D-PAGE. We used seven OSCC cell lines (Ca9-22, OK92, Ho-1-N-1, H1, HSC-4, Sa3, SAS) and five NOK strains. When the cultured cells grew into a full monolayer, they were washed with cold PBS (Sigma) three times and treated with lysis buffer containing $30 \mathrm{mM}$ Tris- $\mathrm{HCl}(\mathrm{pH} 7.5), 150 \mathrm{mM} \mathrm{NaCl}, 1 \%$ Triton $\mathrm{X}-100,10 \%$ glycerol and protease inhibitor cocktail to generate protein lysates for $10 \mathrm{~min}$ at $4{ }^{\circ} \mathrm{C}$. The cells were collected using a scraper and centrifuged at $15000 \mathrm{x} \mathrm{g}$ for $10 \mathrm{~min}$ at $4^{\circ} \mathrm{C}$. Protein concentrations were determined by 
the Bradford method. Total protein concentrations were normalized to $1 \mu \mathrm{g} / \mu \mathrm{l}$ for all samples, and samples were stored at $-20^{\circ} \mathrm{C}$ until use.

For $2 \mathrm{D}-\mathrm{PAGE}$, each protein sample $(100 \mu \mathrm{g})$ was mixed with sample buffer containing $7 \mathrm{M}$ urea, $2 \mathrm{M}$ thiourea, $4 \%$ (w/v) 3-[(3-cholamidopropyl)dimethylammonio]-1-propanesulfonic acid, and $1 \%(\mathrm{w} / \mathrm{v})$ dithiothreiol. Isoelectric focusing for the first dimension of protein separation was performed using a Multiphore II electrophoresis system (Amersham Biosciences, Piscataway, NJ). Immobiline Dry IPG strips $(7 \mathrm{~cm}$, pH 3.0-10.0 nonlinear IPG strips; Amersham Biosciences) were rehydrated overnight with sample/rehydration buffer mixture. The strips were subjected to electrophoresis using a ramping IPG strip (200-5000 V) focusing algorithm. After isoelectric focusing, the gel strips were equilibrated with sodium dodecyl sulfate (SDS) equilibration buffer and electrophoresed in vertical SDS-PAGE slab gels containing $12.5 \%$ acrylamide. Gels of the microdissected samples then were fixed and silver-stained using Silver Quest silver staining kit (Invitrogen Japan, K.K., Tokyo, Japan), according to the manufacturer's instructions.

$2 D$ gel analysis and MALDI-TOF-mass. The silver-stained gels were scanned into Adobe Photoshop 4.0J (Adobe, San Jose, CA) using a Umax PowerLook II scanner (Umax, Dallas, TX) and printed. Differences in protein levels were defined as clear visual differences in size, density, or both of the protein spot on the gel.

Phoretix 2D Advanced software (version 5.01; Nonlinear Dynamic, Ltd., Newcastle, UK) was used to estimate the relative differences in spot intensity for a candidate protein. Spots that were consistently and significantly different were selected for analysis by MALDI-TOF-mass. The protein spots were excised from the gels, and in-gel digestion was performed with an enzyme solution containing $50 \mathrm{mM} \mathrm{NH} \mathrm{NCO}_{3}, 5 \mathrm{mM}$ $\mathrm{CaCl}_{2}$, and $12.5 \mathrm{ng} / \mu \mathrm{l}$ trypsin. Aliquots of the purified samples were spotted on matrix crystals of $\alpha$-cyano-4-hydroxylcinnamic acid on a stainless-steel target and air-dried. Mass determinations were performed on the AXIMA-CFR mass spectrometer (Shimadzu Co. Ltd., Kyoto, Japan). The proteins were identified by the peptide-mass fingerprinting (PMF) method using Mascot Search on the Web (Matrix Science, Ltd., London, UK).

Reverse transcription-PCR (RT-PCR). Total RNA from 12 OSCC cell lines (HSC-2, HSC-3, HSC-4, Ho-1-N-1, OK92, Ca9-22, SKN3, Kosc2, KON, SAT, SAS, Sa3) and the NOK strains was isolated using TRIzol Reagent (Invitrogen Corp., Carlsbad, CA), according to the manufacturer's protocol. Total RNA $(1.0 \mu \mathrm{g})$ was reverse transcribed with Superscript II Rnase $\mathrm{H}^{-}$reverse transcriptase (Invitrogen Corp.) and oligo(dT) primer (Sigma Genosys, Ishikari, Japan), according to the manufacturer's protocol. The primer sequences used for analysis of ITPKA mRNA expression were 5'-GGCGTCA GGACTTACCTAGA-3' (nucleotides 850-869) and 5'-AGC ACTTCCTCATCTCCTTG-3' (nucleotides 1163-1144). The sequence of specific primers was checked before use using the Primer3 program (http:www-genome.wi.mit.edu/cgibin/ primer/primer3_www.cgi) to avoid amplification of genomic DNA or pseudogenes. Real-time quantitative RT-PCR was performed using the LightCycler FastStart DNA Master SYBR-Green I kit (Roche Diagnostics GmbH, Mannheim, Germany). PCR reactions using LightCycler (Roche) apparatus were carried out in a final volume of $20 \mu 1$ of reaction mixture consisting of $2 \mu \mathrm{l}$ of FirstStart DNA Master SYBR-Green I mix (Roche), $3 \mathrm{mM} \mathrm{MgCl}, 1 \mu \mathrm{M}$ of the primers, and $50 \mathrm{ng}$ of template cDNA, according to the manufacturer's instructions. The reaction mixture then was loaded into glass capillary tubes and submitted to initial denaturation at $95^{\circ} \mathrm{C}$ for $10 \mathrm{~min}$, followed by 45 rounds of amplification at $95^{\circ} \mathrm{C}(10 \mathrm{sec})$ for denaturation, $68^{\circ} \mathrm{C}(10 \mathrm{sec})$ for annealing, and $72^{\circ} \mathrm{C}$ for extension, with a temperature slope of $20^{\circ} \mathrm{C} / \mathrm{sec}$ performed in the LightCycler. The transcript amount for the ITPKA gene was estimated from the respective standard curves and normalized to the glyceraldehyde-3-phosphate dehydrogenase (GAPDH) transcript amount determined in corresponding samples.

Western blotting. The protein samples from the 12 OSCC cell lines (HSC-2, HSC-3, HSC-4, Ho-1-N-1, OK92, Ca9-22, SKN3, Kosc2, KON, SAT, SAS, Sa3), the NOK strains, and rat brain were prepared as previously described. Protein extracts from the latter two were used as positive controls. Samples containing $30 \mu \mathrm{g}$ of protein were electrophoresed on $12.5 \%$ SDS-polyacrylamide electrophoresis gels and transferred to Immunoblot PVDF membranes (Bio-Rad, Hercules, CA). Equal loading of protein was confirmed by silver-staining. Membranes were blocked for $1 \mathrm{~h}$ with $5 \%$ non-fat skim milk

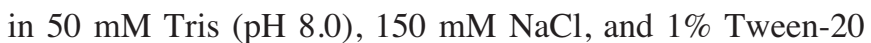
(TBS-T) at room temperature. After the membranes were washed three times with TBS-T, the blots were incubated for $2 \mathrm{~h}$ with $0.8 \mu \mathrm{g} / \mathrm{ml}$ affinity-purified goat antihuman ITPKA polyclonal antibody (Santa Cruz Biotechnology, Santa Cruz, CA) in TBS-T containing 5\% non-fat skim milk at room temperature. The membranes were washed briefly in TBS-T and incubated with a 1:5000 of antigoat IgG as secondary antibody for $20 \mathrm{~min}$ at room temperature. After several washings, the blots were developed using ECL and Western blotting detection reagents (Amersham), and immunoblotting was visualized by exposing the membrane to X-ray film.

IHC. Formalin-fixed, paraffin-embedded serial tissue sections were cut at 4 microns, deparaffinized in xylene, and rehydrated in a series of graded ethanol. Antigen retrieval for ITPKA was performed using citrate buffer with a microwave method. Hydrogen peroxide $(0.3 \%)$ was used to quench endogenous peroxidase activity. The sections were incubated first with $1.5 \%$ blocking serum (Santa Cruz Biotechnology) for $1 \mathrm{~h}$ at room temperature to block non-specific staining and then with affinity-purified goat antihuman ITPKA polyclonal antibody (Santa Cruz Biotechnology) at a dilution of 1:40 overnight at $4^{\circ} \mathrm{C}$ in a moist chamber. Immunodetection was performed using the avidin-biotin-peroxidase complex method (Santa Cruz Biotechnology), according to the manufacturer's instruction. Finally, the slides were counterstained with hematoxylin, dehydrated, and cover-slipped with permanent mounting medium. As a negative control, duplicate sections were immunostained without exposure to primary antibodies. To quantitate ITPKA protein expression, a scoring method was used in which the mean percentage of positive tumor cells 


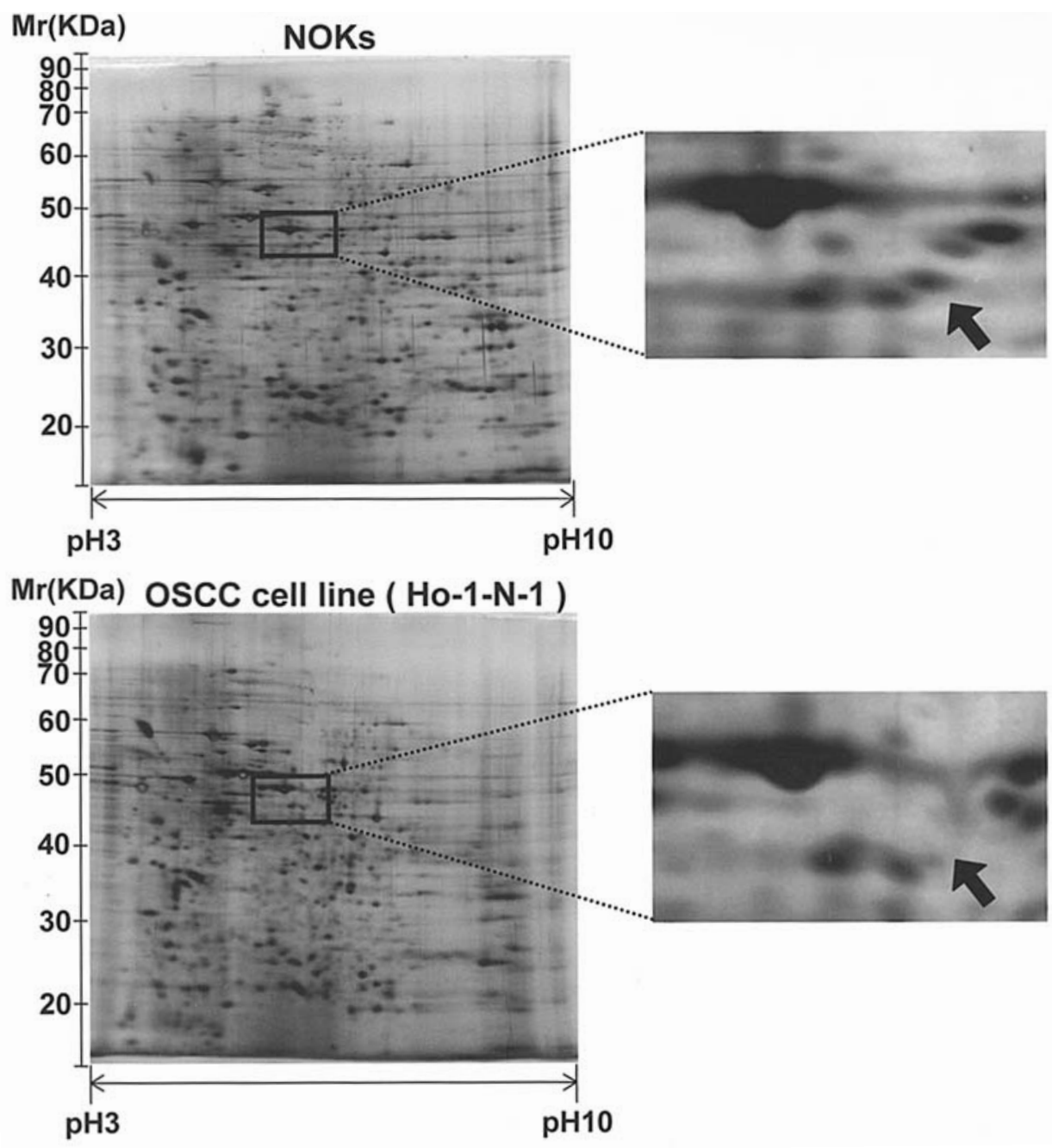

Figure 1. Representative master 2D-gel images and detailed alteration patterns of ITPKA protein in NOK strains and OSCC cell line samples.

Table I. Results of MALDI-TOF MS spectra and database analysis for protein identification.

\begin{tabular}{|c|c|c|c|c|}
\hline Protein name & $\begin{array}{l}\text { Peptides } \\
\text { matched }\end{array}$ & $\begin{array}{c}\text { Sequence } \\
\text { coverage }(\%)\end{array}$ & $\begin{array}{c}\text { MOWSE } \\
\text { score }^{\mathrm{a}}\end{array}$ & Change ${ }^{b}$ \\
\hline Creatine kinase, mitochondrial & 8 & 20 & 97 & Decrease \\
\hline 1D-myo-inositol 1,4,5-trisphosphate 3-kinase A & 6 & 19 & 69 & Decrease \\
\hline Acetyl-coenzyme A acyltransferase & 9 & 28 & 92 & Decrease \\
\hline Aldolase C, fructose-bisphosphate & 9 & 23 & 86 & Increase \\
\hline Similar to hydroxyacyl-coenzyme A dehydrogenase & 8 & 37 & 106 & Increase \\
\hline Dystrophin-related protein 3 & 8 & 19 & 70 & Increase \\
\hline
\end{tabular}

${ }^{\mathrm{a} M O W S E}$ scores over 67 were significant $(\mathrm{P}<0.05)$. ${ }^{\text {bn }}$ OSSC cells compared to NOKs.

was determined in at least five random fields at magnification $\mathrm{x} 400$ in each section. The intensity of the ITPKA immunoreaction was scored as follows: $1+$, weak; $2+$, moderate; and $3+$, intense. The percentage of positive tumor cells and the staining intensity then were multiplied to produce an ITPKAIHC staining score for each case. Cases with an ITPKA-IHC score of less than 38, the minimal score in normal tissue, were defined as ITPKA-negative. Two independent pathologists with no knowledge of the patients' clinical status scored the cases. Statistical differences between the ITPKA-IHC scores and the clinicopathological features were determined by the $\chi^{2}$ for independence test or the Mann-Whitney $U$ test. In 


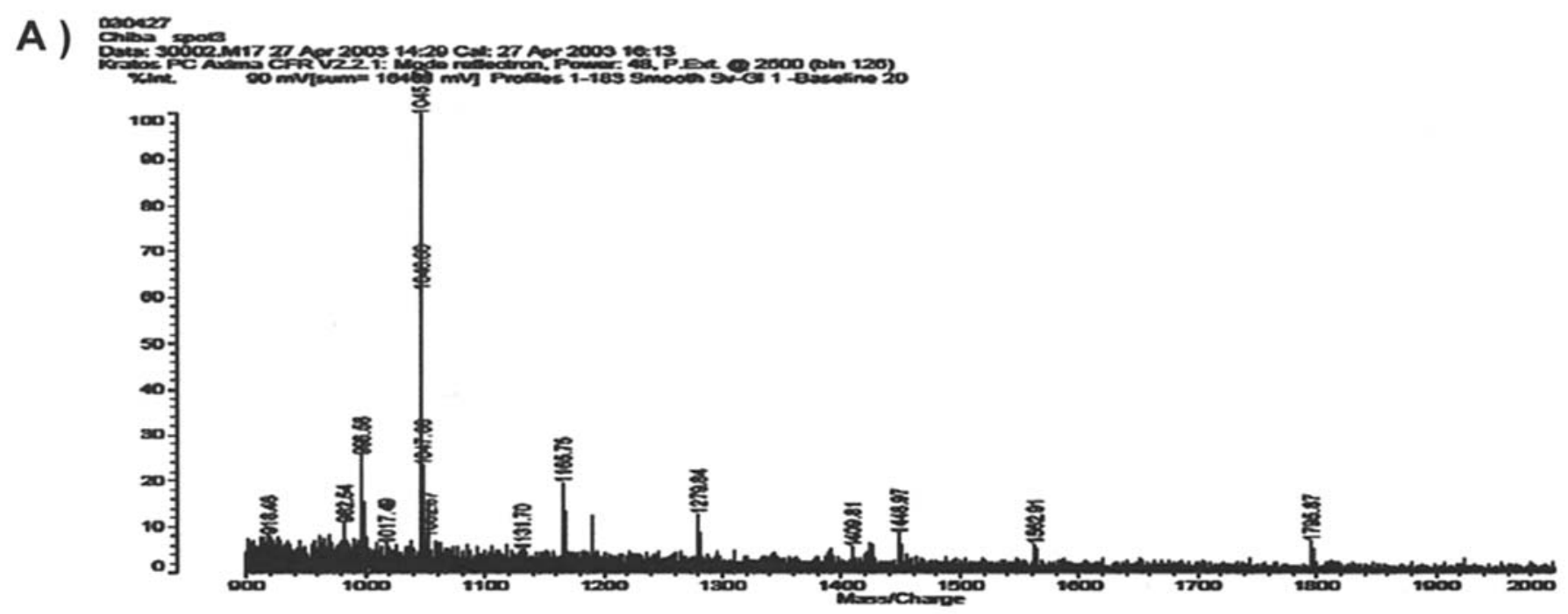

(B) MTLPGHPTGM ARPRGAGPCS PGLERAPRRS VGELRLLFEA RCAAVAAAAA AGEPRARGAK RRGGQVPNGL PRAAPAPVIP QLTVTSEEDV APASPGPPDR EGNWLPAAGS HLQQPRRLST SSLSSTGSSS LLEDSEDDLL SDSESRSRGN VQLETSEDVG OKSHWOKIRT MVNLPVMSPF KKRYSWVQLA GHTGSFKAAG TSGLILKRSS EPEHYCLVRL MADVLRGCVP AFHGVVERDG ESYLQLQDLL DGFDGPCVLD CKMGVRTYLE EELTKARERP KLRKDMYKKM LAVDPEAPTE EEHAQRAVTK PRYMQWREGI SSSTTLGFRI EGIKKADGSC STDFKTTRSR EQVTRVFEEF MQGDAEVLKR YLNRLQQIRD TLEISDFFRR HEVIGSSLLF VHDHCHRAGV WLIDFGKTTP LPDGQILDHR RPWEEGNRED GYLLGLDNLI GILANLAER

Figure 2. (A), Mass spectometry of ITPKA by MALDI-TOF-mass. (B), The amino acid sequences of the ITPKA protein analyzed by the PMF method are underlined in the full-length sequence of the protein.

addition, statistical analysis of the ITPKA-IHC scores of histopathological type was performed using the Mann-Whitney $\mathrm{U}$ test. $\mathrm{p}<0.05$ was considered significant.

\section{Results}

Protein separation by 2D-PAGE. Fig. 1 shows typical master gel images of the NOK strains and OSCC cell line samples. About 750 protein spots in each gel were detected using the Phoretix Two-Dimensional Advanced v5.01 analysis program. When we compared the protein spots from seven OSCC cell lines (Ca9-22, OK92, Ho-1-N-1, H1, HSC-4, Sa3, SAS) with five NOK strains, we found that three protein spots common to both showed increases and 27 protein spots common to both showed decreases.

Protein identification by $P M F$. We selected three protein spots that increased in the OSCC cell lines and three of the 27 that decreased in the OSCC cell lines because their expression levels were more intense than the other 24 spots in the NOK strains. Each protein spot was excised and subjected to in-gel tryptic digestion, MALDI-TOF-mass, and database matching. Isoforms with an identical primary structure in the protein matching were classified as one protein. Table I shows the six proteins identified; most of the matched proteins had high sequence coverage, mass accuracy, and MOWSE scores. Fig. 1 shows the changes in expression levels of the identified ITPKA protein in the OSCC cell lines and NOK strains. The ITPKA protein levels dramatically decreased in the OSCC cell lines.

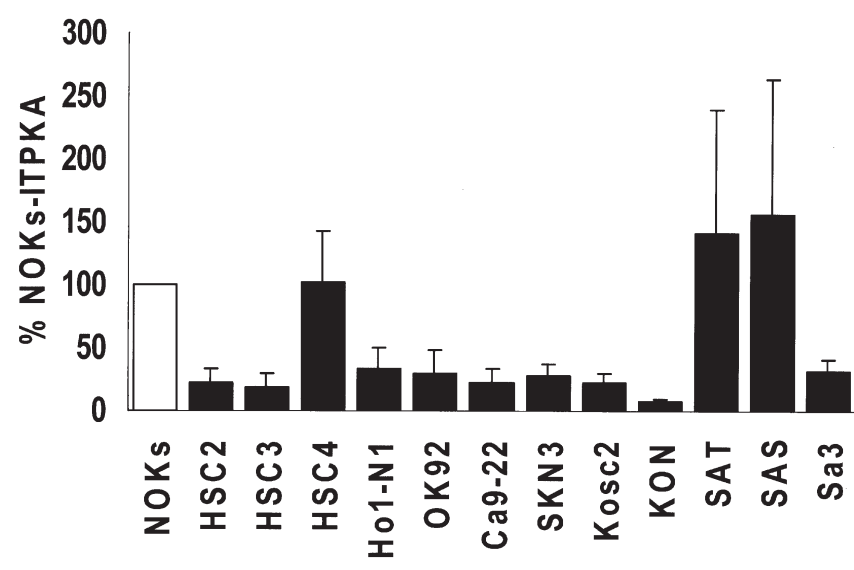

Figure 3. ITPKA mRNA expression status in OSCC cell lines by real-time quantitative RT-PCR analysis. Nine of 12 (75\%) OSCC cell lines have significantly down-regulated ITPKA mRNA expression compared to the NOK strains. Data are expressed as the means \pm SD.

Fig. 2 shows the results of mass spectometry and the matched sequence of ITPKA.

Expression of ITPKA. Nine of 12 (HSC-2, HSC-3, Ho-1N-1, OK92, Ca9-22, SKN3, Kosc2, KON, Sa3) OSCC cell lines $(75 \%)$ had significantly down-regulated ITPKA mRNA expression on real-time quantitative RT-PCR compared with the NOK strains used as a control (Fig. 3). Three OSCC cell lines (HSC-4, SAT, SAS) did not show down-regulated ITPKA 




Figure 4. The ITPKA protein expression status in OSCC cell lines by Western blotting. The ITPKA protein expression of all OSCC cell lines is significantly reduced compared with that of the rat brain (lane PC) and NOK strains used as positive controls.
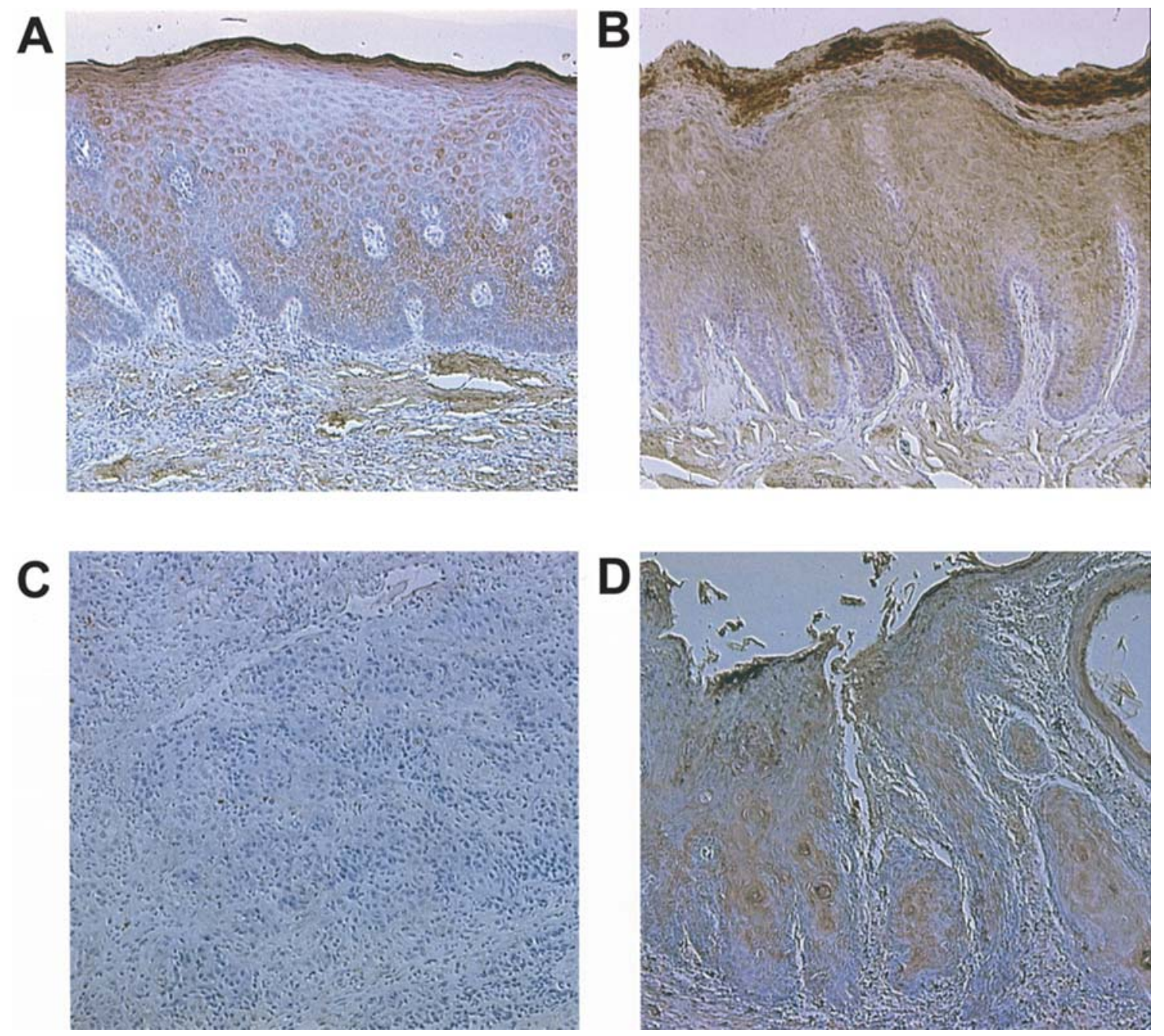

Figure 5. IHC staining of ITPKA in normal oral tissue, OPL, and primary OSCCs. (A) Normal oral tissue exhibits cytoplasmic immunoreaction of ITPKA in prickle, granular, and corneum cell layers but not in the basal cell layer. (B) OPL (leukoplakia) exhibits strong positive immunoreaction for ITPKA. (C) ITPKA-negative case of primary OSCC. (D) ITPKA-positive case of primary OSCC. Original magnification x200.

mRNA expression, although their ITPKA protein expression levels were significantly reduced. The data shown are the mean of three independent experiments with triplicate samples and are expressed as the mean $\pm \mathrm{SD}$.

Protein expression of ITPKA. The ITPKA protein expression levels of all OSCC cell lines were significantly reduced compared with the rat brain and NOK strains used as positive controls (Fig. 4). Western blot analysis data from six OSCC cell lines (Ca9-22, OK92, Ho-1-N-1, HSC-4, Sa3, SAS) were matched to their respective protein expression states studied using 2D-PAGE analysis.

IHC. Among 100 OSCCs analyzed by IHC staining, 40 had significantly decreased expression of ITPKA (IHC score <38). In contrast, all normal tissue revealed a strong cytoplasmic immunoreaction of ITPKA in the prickle, granular, and corneum cell layers but not in the basal cell layer. In oral premalignant lesions (OPLs), all 33 were ITPKA-positive. The representative results for ITPKA protein expression in 
Table II. Correlation between expression of ITPKA and clinical classification in OSCC.

\begin{tabular}{|c|c|c|c|c|}
\hline \multirow[b]{2}{*}{ Clinical classification } & \multicolumn{3}{|c|}{$\begin{array}{c}\text { Results of immunostaining } \\
\text { No. of patients }(\%)\end{array}$} & \multirow[b]{2}{*}{ P-value } \\
\hline & Total & $\begin{array}{c}\text { ITPKA } \\
(-)\end{array}$ & $\begin{array}{c}\text { ITPKA } \\
(+)\end{array}$ & \\
\hline
\end{tabular}

$\begin{array}{lccc}\begin{array}{l}\text { Age at surgery (years) } \\ <60\end{array} & 34 & 15(44) & 19(56) \\ 60-69 & 29 & 14(48) & 15(52) \\ \geq 70 & 37 & 11(30) & 26(70) \\ \text { Gender } & & & \\ \text { Male } & 53 & 21(40) & 32(60) \\ \text { Female } & 47 & 19(40) & 28(60) \\ \text { T-primary tumor } & & & \\ \text { T1 } & 9 & 6(67) & 3(33) \\ \text { T2 } & 54 & 25(46) & 29(54) \\ \text { T3 } & 9 & 3(33) & 6(67) \\ \text { T4 } & 28 & 6(21) & 22(79)\end{array}$

N-regional lymph

node

\begin{tabular}{|c|c|c|c|}
\hline N (-) & 68 & $30(44)$ & $38(56)$ \\
\hline $\mathrm{N}(+)$ & 32 & $10(31)$ & $22(69)$ \\
\hline
\end{tabular}

Stage

$\begin{array}{lcrrr}\text { I } & 8 & 5(62) & 3(38) & 0.661 \\ \text { II } & 38 & 20(53) & 18(47) & \\ \text { III } & 15 & 5(33) & 10(67) & \\ \text { IV } & 39 & 10(26) & 29(74) & \end{array}$

Histopathological type

$\begin{array}{lcrc}\text { Well differentiated } & 67 & 22(33) & 45(67) \\ \text { Moderately differentiated } & 27 & 13(48) & 14(52) \\ \text { Poorly differentiated } & 6 & 5(80) & 1(20)\end{array}$

Tumor site

\begin{tabular}{lcrcc} 
Gingiva & 38 & $8(21)$ & $30(79)$ & 0.936 \\
Tongue & 37 & $17(46)$ & $20(54)$ & \\
Buccal mucosa & 11 & $5(45)$ & $6(55)$ & \\
Oral floor & 7 & $6(86)$ & $1(14)$ \\
Oropharyngeal isthmus & 6 & $4(67)$ & $2(33)$ \\
Lip & 1 & 0 & $(0)$ & $1(100)$ \\
\hline
\end{tabular}

normal oral tissue, OPLs, and primary OSCCs are shown in Fig. 5. There were statistically significant differences in clinicopathological features between ITPKA-negative and ITPKA-positive cases by histopathological type (Table II). The ITPKA-IHC scores for normal tissue, OPLs, and primary OSCCs that are well, moderately, and poorly differentiated respectively ranged from 38-155 (mean, 52 $\pm 17.2 \mathrm{SD}$ ), 40-162

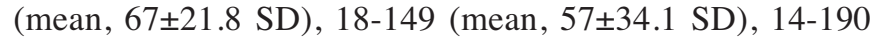
(mean, 53 $\pm 43.4 \mathrm{SD}$ ), and 14-55 (mean, 26 $\pm 15.1 \mathrm{SD}$ ). We found some significant differences in ITPKA-IHC scores by histopathological type (Fig. 6).

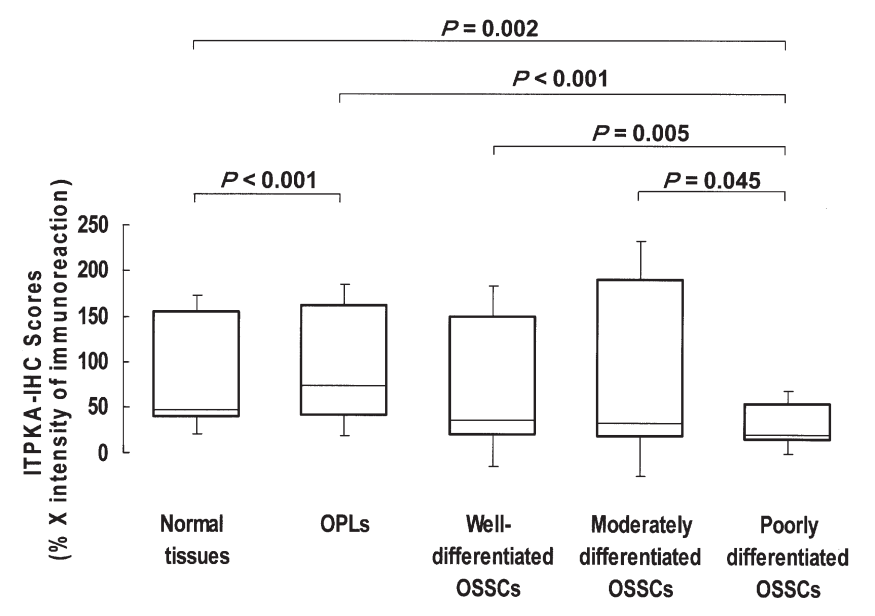

Figure 6. State of ITPKA protein expression in normal oral tissue $(n=100)$, OPLs $(n=33)$, primary OSCCs that are well $(n=67)$, moderately $(n=27)$, and poorly differentiated $(n=6)$. There were statistically significant differences between normal oral tissue, OPLs, and primary OSCCs that are poorly differentiated. In addition, there were statistically significant differences between primary OSCCs that are well, moderately, and poorly differentiated. Results are expressed as the ranges and the means \pm SD.

\section{Discussion}

We identified six proteins using 2D-PAGE analysis, MALDITOF-mass, and the PMF method: mitochondrial creatine kinase is responsible for the transfer of high-energy phosphate from mitochondria to the cytosolic carrier, creatine (28); ITPKA phosphorylate $\operatorname{Ins}(1,4,5) \mathrm{P}_{3}$ regulates intracellular $\mathrm{Ca}^{2+}$ homeostasis (1-3); acetyl-coenzyme A acyltransferase is an enzyme in the $\beta$-oxidation system of the peroxisomes (29); idolase C, fructose-bisphosphate is a glycolytic enzyme in mammalian brain (30); hydroxyacyl-coenzyme A dehydrogenase is an enzyme associated with fatty acid $\beta$-oxidation (31); and dystrophin-related protein 3 is a peripheral membrane protein associated with dystrophin and dystrophin-related proteins (32). Of these, we selected ITPKA because it has not been reported in oncogenesis.

When we compared the OSCC cell lines with the NOK strains, the expression level of ITPKA protein was dramatically decreased in Western blotting, as indicated by proteomics analysis, whereas, ITPKA mRNA expression was downregulated in nine of $12(75 \%)$ OSCC cell lines. Thus, the results suggest that post-transcriptional regulation and posttranslational modifications may be related to ITPKA downexpression. On the other hand, high frequent loss of heterozygosity (LOH) was found at chromosome 15q14-21 near the genomic region containing ITPKA, which has been reported to be the region involving the tumor suppressor gene in human tumors, including head and neck SCCs (33-39). Therefore, $\mathrm{LOH}$ also may be related to ITPKA down-expression.

We found statistically significant differences by histopathological type. As the differentiation became less pronounced, the mean IHC scores became increasingly smaller. In SCC, the differentiated degree means the difference in the keratinizing state. ITPKA expression may be related to the process of keratinization for two reasons: first, ITPKA expression was seen in the prickle, granular, and corneum cell layer but not in the basal cell layer; and second, there was 
intense immunoreaction of ITPKA in the parts that were well keratinized, such as cancer pearl and OPLs. Furthermore, $\mathrm{Ca}^{2+}$ is a known regulator of epithelial differentiation. The increase in the intracellular $\mathrm{Ca}^{2+}$ level, which ITPKA partly regulates, stimulates the terminal differentiation of NOKs in culture. The inability of SCC lines to differentiate is related to a defect in achieving adequate levels of $\mathrm{Ca}^{2+}(40-44)$. Based on this evidence, we speculate that ITPKA expression, which is thought to control a critical level of cytosolic $\mathrm{Ca}^{2+}$, may trigger the mechanisms required for initiation of SCC differentiation.

ITPKA may not only be related to differentiation of SCC by $\mathrm{Ca}^{2+}$ regulation but also may influence various intracellular biological responses by controlling inositol polyphosphate metabolism because ITPKA produces $\operatorname{Ins}(1,3,4,5) \mathrm{P}_{4}$ and various inositol polyphosphates that are involved in several aspects of cell regulation. For example, $\operatorname{Ins}(1,3,4,5) \mathrm{P}_{4}$ is thought to control $\mathrm{Ca}^{2+}$ entry from the extracellular fluid across the plasma membrane together with $\operatorname{Ins}(1,4,5) \mathrm{P}_{3}(2,45-50)$. As a result, down-regulation of ITPKA may lead to reduced $\mathrm{Ca}^{2+}$ influx into the cell. In addition, $\operatorname{Ins}(1,3,4,5) \mathrm{P}_{4}$ also may play a role in regulating cross-talk between $\mathrm{Ca}^{2+}$ and other signaling pathways, because an $\operatorname{Ins}(1,3,4,5) \mathrm{P}_{4}$ binding protein has been identified that can stimulate the GTPase activity of the ras and rap small GTP binding proteins $(51,52)$. Moreover, Ins $(1,3,4,5) \mathrm{P}_{4}$ activates $\mathrm{K}^{+}$channels in the plasma membrane in cooperation with the internal $\mathrm{Ca}^{2+}$ (53). In the same way, ITPKA down-expression may impair these functions. The physiological roles of other inositol polyphosphates, formed via the dephosphorylation or phosphorylation pathways downstream of Ins $(1,3,4,5) \mathrm{P}_{4}$, have not yet been established (1,54-60). However, the function of inositol 3,4,5,6-tetrakisphosphate regulates $\mathrm{Ca}^{2+}$-dependent chloride conductance (61). Based on these reports, we presumed that decreased production of $\operatorname{Ins}(1,3,4,5) \mathrm{P}_{4}$ and inositol polyphosphates by ITPKA down-expression alters the intracellular biological responses including oncogenesis.

Although we initially hypothesized that ITPKA may be a tumor-suppressor gene for down-expression compared to NOKs in OSCC cell lines, we did not find histopathological evidence of this. Alternatively, we propose that down-regulation of ITPKA might contribute to several aspects of acquisition, progression, and maintenance of the malignant phenotype via irregular $\mathrm{Ca}^{2+}$ homeostasis and inositol polyphosphate metabolism. Histopathological differentiation of carcinoma frequently correlates with the prognosis of cancer. Therefore, ITPKA may be a potential novel prognostic marker, a therapeutic molecular target of cancer, or both in future studies of the complexity of cytosolic $\mathrm{Ca}^{2+}$ regulation using a greater number of clinical samples.

\section{Acknowledgements}

We thank Dr Takaki Hiwasa (Department of Biochemistry and Genetics, Graduate School of Medicine, Chiba University) and Dr Yasuo Iwadate (Department of Neurological Surgery, Graduate School of Medicine, Chiba University) for their helpful advice on 2D-PAGE and MALDI-TOF-mass, and Ms. Lynda C. Charters for editing this manuscript. This study was partly supported by a Grant-in-Aid (no.16209059) from the Ministry of Education, Science, Sports and Culture of Japan.

\section{References}

1. Berridge MJ and Irvine RF: Inositol phosphates and cell signaling. Nature 341: 197-205, 1989.

2. Irvine RF: Inositol tetrakisphosphate as a second messenger: confusions, contradictions, and a potential resolution. Bioessays 13: 419-427, 1991.

3. Woodring PJ and Garrison JC: Expression, purification, and regulation of two isoforms of the inositol 1,4,5-trisphosphate 3-kinase. J Biol Chem 272: 30447-30454, 1997.

4. Berridge MJ, Lipp P and Bootman MD: The versatility and universality of calcium signalling. Nat Rev Mol Cell Biol 1: $11-21,2000$

5. Berridge MJ, Bootman MD and Roderick HL: Calcium signalling: dynamics, homeostasis and remodelling. Nat Rev Mol Cell Biol 4: 517-529, 2003.

6. Hanson PI and Schulman $\mathrm{H}$ : Neuronal $\mathrm{Ca}^{2+} /$ calmodulin-dependent protein kinases. Annu Rev Biochem 61: 559-601, 1992.

7. Berridge MJ: Inositol trisphosphate and calcium signalling. Nature 361: 315-325, 1993.

8. Baldassare JJ and Fisher GJ: Regulation of membrane-associated and cytosolic phospholipase $\mathrm{C}$ activities in human platelets by guanosine triphosphate. J Biol Chem 261: 11942-11944, 1986.

9. Irving HR and Exton JH: Phosphatidylcholine breakdown in rat liver plasma membranes. Roles of guanine nucleotides and P2-purinergic agonists. J Biol Chem 262: 3440-3443, 1987.

10. Berridge MJ: Inositol trisphosphate and diacylglycerol as second messengers. Biochem J 220: 345-360, 1984.

11. Berridge MJ: Inositol trisphosphate and diacylglyceol: two interacting second messengers. Annu Rev Biochem 56: 159-193, 1987.

12. Tsien RW and Tsien RY: Calcium channels, stores, and oscillations. Annu Rev Cell Biol 6: 715-760, 1990.

13. Vanweyenberg V, Communi D, D'Santos CS and Erneux C: Tissue- and cell-specific expression of $\operatorname{Ins}(1,4,5) \mathrm{P}_{3}$ 3-kinase isoenzymes. Biochem J 306: 429-435, 1995.

14. Johanson RA, Hansen CA and Williamson JR: Purification of D-myo-inositol 1,4,5-trisphosphate 3-kinase from rat brain. J Biol Chem 263: 7465-7471, 1988.

15. Dewaste V, Moreau C, De Smedt F, Bex F, De Smedt F, Wuytack F, Missiaen L and Erneux C: The three isoenzymes of human inositol-1,4,5-trisphosphate 3-kinase show specific intracellular localization but comparable $\mathrm{Ca}^{2+}$ responses on transfection in COS-7 cells. Biochem J 374: 41-49, 2003.

16. Sim SS, Kim JW and Rhee SG: Regulation of D-myo-inositol 1,4,5-trisphosphate 3-kinase by cAMP-dependent protein kinase and protein kinase C. J Biol Chem 265: 10367-10372, 1990.

17. Takazawa K, Vandekerckhove J, Dumont JE and Erneux C: Cloning and expression in Escherichia coli of a rat brain cDNA encoding a $\mathrm{Ca}^{2+} /$ calmodulin-sensitive inositol 1,4,5-trisphosphate 3-kinase. Biochem J 272: 107-112, 1990.

18. Yamaguchi K, Hirata M and Kuriyama H: Calmodulin activates inositol 1,4,5-trisphosphate 3-kinase activity in pig aortic smooth muscle. Biochem J 244: 787-791, 1987.

19. Sudbrak R, Brown J, Dobson-Stone C, Carter S, Ramser J, White J, Healy E, Dissanayake M, Larregue M, Perrussel M, Lehrach H, Munro CS, Strachan T, Burge S, Hovnanian A and Monaco AP: Hailey-Hailey disease is caused by mutations in ATP2C1 encoding a novel $\mathrm{Ca}^{2+}$ pump. Hum Mol Genet 9: 1131-1140, 2000.

20. Hu Z, Bonifas JM, Beech J, Bench G, Shigihara T, Ogawa H, Ikeda S, Mauro T and Epstein EH Jr: Mutations in ATP2C1, encoding a calcium pump, cause Hailey-Hailey disease. Nat Genet 24: 61-65, 2000.

21. Sakuntabhai A, Ruiz-Perez V, Carter S, Jacobsen N, Burge S, Monk S, Smith M, Munro CS, O'Donovan M, Craddok N, Kucherlapati R, Rees JL, Owen M, Lathrop GM, Monaco AP, Strachan T and Hovnanian A: Mutations in ATP2A2, encoding a Ca ${ }^{2+}$ pump, cause Darier disease. Nat Genet 21: 271-277, 1999.

22. Ruiz-Perez VL, Carter SA, Healy E, Todd C, Rees JL, Steijlen PM, Carmichael AJ, Lewis HM, Hohl D, Itin P, Vahlquist A, Gobello T, Mazzanti C, Reggazini R, Nagy G, Munro CS and Strachan T: ATP2A2 mutations in Darier's disease: variant cutaneous phenotypes are associated with missense mutations, but neuropsychiatric features are independent of mutation class. Hum Mol Genet 8: 1621-1630, 1999. 
23. Sakuntabhai A, Burge S, Monk S and Hovnanian A: Spectrum of novel ATP2A2 mutations in patients with Darier's disease. Hum Mol Genet 8: 1611-1619, 1999.

24. Liu LH, Boivin GP, Prasad V, Periasamy M and Shull GE: Squamous cell tumors in mice heterozygous for a null allele of Atp2a2, encoding the sarco (endo) plasmic reticulum $\mathrm{Ca}^{2+}$ ATPase isoform $2 \mathrm{Ca}^{2+}$ pump. J Biol Chem 276: 26737-26740, 2001.

25. Prasad V, Okunade GW, Miller ML and Shull GE: Phenotypes of SERCA and PMCA knockout mice. Biochem Biophys Res Commun 322: 1192-1203, 2004.

26. Endo Y, Uzawa K, Mochida Y, Shiba M, Bukawa H, Yokoe H and Tanzawa H: Sarcoendoplasmic reticulum $\mathrm{Ca}^{2+}$ ATPase type 2 downregulated in human oral squamous cell carcinoma. Int $\mathbf{J}$ Cancer 110: 225-231, 2004.

27. Seishima M, Esaki C, Osada K, Mori S, Hashimoto T and Kitajima Y: Pemphigus IgG, but not bullous pemphigoid IgG, causes a transient increase in intracellular calcium and inositol 1,4,5-triphosphate in DJM-1 cells, a squamous cell carcinoma line. J Invest Dermatol 104: 33-37, 1995.

28. Haas RC, Korenfeld C, Zhang ZF, Perryman B, Roman D and Strauss AW: Isolation and characterization of the gene and cDNA encoding human mitochondrial creatine kinase. J Biol Chem 264: 2890-2897, 1989.

29. Schram AW, Goldfischer S, van Roermund CW, BrouwerKelder EM, Collins J, Hashimoto T, Heymans HS, van den Bosch H, Schutgens RB, Tager JM and Wanders RJ: Human peroxisomal 3-oxoacyl-coenzyme A thiolase deficiency. Proc Natl Acad Sci USA 84: 2494-2496, 1987.

30. Buono P, Barbrieri O, Alfieri A, Rosica A, Astigiano S, Cantatore D, Mancini A, Fattoruso O and Salvatore F: Diverse human aldolase $\mathrm{C}$ gene promoter regions are required to direct specific LacZ expression in the hippocampus and Purkinje cells of transgenic mice. FEBS Lett 578: 337-344, 2004.

31. Matsuoka S, Saito T, Kuwayama H, Morita N, Ochiai H and Maeda M: MFE1, a member of the peroxisomal hydroxyacyl coenzyme A dehydrogenase family, affects fatty acid metabolism necessary for morphogenesis in Dictyostelium spp. Eukaryot Cell 2: 638-645, 2003

32. Sherman DL, Fabrizi C, Gillespie CS and Brophy PJ: Specific disruption of a Schwann cell dystrophin-related protein complex in a demyelinating neuropathy. Neuron 30: 677-687, 2001.

33. Wick W, Petersen I, Schmutzler RK, Wolfarth B, Lenartz D, Bierhoff E, Hummerich J, Muller DJ, Stangl AP, Schramm J, Wiestler OD and von Deimling A: Evidence for a novel tumor suppressor gene on chromosome 15 associated with progression to a metastatic stage in breast cancer. Oncogene 12: 973-978, 1996.

34. Kersemaekers AM, Kenter GG, Hermans J, Fleuren GJ and van de Vijver MJ: Allelic loss and prognosis in carcinoma of the uterine cervix. Int J Cancer 79: 411-417, 1998.

35. Schmutte C, Tombline G, Rhiem K, Sadoff MM, Schmutzler R, von Deimling A and Fishel R: Characterization of the human Rad51 genomic locus and examination of tumors with 15q1415 loss of heterozygosity (LOH). Cancer Res 59: 4564-4569, 1999.

36. Gonzalez R, Silva JM, Dominguez G, Garcia JM, Martinez G, Vargas J, Provencio M, Espana P and Bonilla F: Detection of loss of heterozygosity at RAD51, RAD52, RAD54 and BRCA1 and BRCA2 loci in breast cancer: pathological correlations. Br J Cancer 81: 503-509, 1999.

37. Beder LB, Gunduz M, Ouchida M, Fukushima K, Gunduz E, Ito S, Sakai A, Nagai N, Nishizaki K and Shimizu K: Genomewide analyses on loss of heterozygosity in head and neck squamous cell carcinomas. Lab Invest 83: 99-105, 2003.

38. Popat S, Stone J and Houlston RS: Allelic imbalance in colorectal cancer at the CRAC1 locus in early-onset colorectal cancer. Cancer Genet Cytogenet 145: 70-73, 2003.

39. Natrajan R, Louhelainen J, Williams S, Laye J and Knowles MA: High-resolution deletion mapping of 15q13.2-q21.1 in transitional cell carcinoma of the bladder. Cancer Res 63: 7657-7662, 2003.

40. Hoffman HT, Subnani M, Cha M, Kidd L, Landman J, Tooley R and Carey TE: Calcium regulation of antigen expression on normal and malignant human squamous cells in vitro. Arch Otolaryngol Head Neck Surg 116: 299-303, 1990.
41. Yang LC, Ng DC and Bikle DD: Role of protein kinase C $\alpha$ in calcium induced keratinocyte differentiation: defective regulation in squamous cell carcinoma. J Cell Physiol 195: 249-259, 2003.

42. Pillai S, Bikle DD, Mancianti ML and Hincenbergs M: Uncoupling of the calcium-sensing mechanism and differentiation in squamous carcinoma cell lines. Exp Cell Res 192: 567-573, 1991 .

43. Pillai S, Bikle DD, Mancianti ML, Cline P and Hincenbergs M: Calcium regulation of growth and differentiation of normal human keratinocytes: modulation of differentiation competence by stages of growth and extracellular calcium. J Cell Physiol 143: 294-302, 1990 .

44. Tu CL, Oda Y, Komuves L and Bikle DD: The role of the calcium-sensing receptor in epidermal differentiation. Cell Calcium 35: 265-273, 2004.

45. Irvine RF and Moore RM: Inositol $(1,3,4,5)$ tetrakisphosphateinduced activation of sea urchin eggs requires the presence of inositol trisphosphate. Biochem Biophys Res Commun 146: 284-290, 1987.

46. Irvine RF and Moore RM: Micro-injection of inositol 1,3,4,5tetrakisphosphate activates sea urchin eggs by a mechanism dependent on external $\mathrm{Ca}^{2+}$. Biochem J 240: 917-920, 1986.

47. Morris AP, Gallacher DV, Irvine RF and Petersen OH: Synergism of inositol trisphosphate and tetrakisphosphate in activating $\mathrm{Ca}^{2+}$-dependent $\mathrm{K}^{+}$channels. Nature 330: 653-655, 1987.

48. Changya L, Gallacher DV, Irvine RF and Petersen OH: Inositol 1,3,4,5-tetrakisphosphate and inositol 1,4,5-trisphosphate act by different mechanisms when controlling $\mathrm{Ca}^{2+}$ in mouse lacrimal acinar cells. FEBS Lett 251: 43-48, 1989.

49. Hermosura MC, Takeuchi H, Fleig A, Riley AM, Potter BV, Hirata $\mathrm{M}$ and Penner R: InsP $\mathrm{P}_{4}$ facilitates store-operated calcium influx by inhibition of $\operatorname{InsP}_{3}$ 5-phosphatase. Nature 408: 735-740, 2000.

50. Parekh $\mathrm{AB}$ and Penner R: Store depletion and calcium influx. Physiol Rev 77: 901-930, 1997.

51. Cullen PJ, Hsuan JJ, Truong O, Letcher AJ, Jackson TR, Dawson AP and Irvine RF: Identification of a specific Ins $(1,3,4,5) \mathrm{P}_{4}$-binding protein as a member of the GAP1 family. Nature 376: 527-530, 1995.

52. Soriano S and Banting G: Possible roles of inositol 1,4,5trisphosphate 3-kinase B in calcium homeostasis. FEBS Lett 403: 1-4, 1997.

53. Molleman A, Hoiting B, Duin M, van den Akker J, Nelemans A and Den Hertog A: Potassium channels regulated by inositol 1,3,4,5-tetrakisphosphate and internal calcium in $\mathrm{DDT}_{1}$ MF-2 smooth muscle cells. J Biol Chem 266: 5658-5663, 1991.

54. Shears SB: Metabolism of the inositol phosphates produced upon receptor activation. Biochem J 260: 313-324, 1989.

55. Gawler DJ, Potter BV, Gigg R and Nahorski SR: Interactions between inositol tris- and tetrakis-phosphates. Effects on intracellular $\mathrm{Ca}^{2+}$ mobilization in SH-SY5Y cells. Biochem J 276: 163-167, 1991.

56. Ivorra I, Gigg R, Irvine RF and Parker I: Inositol 1,3,4,6-tetrakisphosphate mobilizes calcium in Xenopus oocytes with high potency. Biochem J 273: 317-321, 1991

57. Barker CJ, Wong NS, Maccallum SM, Hunt PA, Michell RH and Kirk CJ: The interrelationships of the inositol phosphates formed in vasopressin-stimulated WRK-1 rat mammary tumour cells. Biochem J 286: 469-474, 1992.

58. Menniti FS, Oliver KG, Nogimori K, Obie JF, Shears SB and Putney JW Jr: Origins of myo-inositol tetrakisphosphates in agonist-stimulated rat pancreatoma cells. Stimulation by bombesin of myo-inositol 1,3,4,5,6-pentakisphosphate breakdown to myoinositol 3,4,5,6-tetrakisphosphate. J Biol Chem 265: 11167-11176, 1990.

59. Oliver KG, Putney JW Jr, Obie JF and Shears SB: The interconversion of inositol 1,3,4,5,6-pentakisphosphate and inositol tetrakisphosphates in AR4-2J cells. J Biol Chem 267: 21528-21634, 1992

60. Barker CJ, Wright J, Hughes PJ, Kirk CJ and Michell RH: Complex changes in cellular inositol phosphate complement accompany transit through the cell cycle. Biochem J 380: 465-473, 2004.

61. Xie W, Kaetzel MA, Bruzik KS, Dedman JR, Shears SB and Nelson DJ: Inositol 3,4,5,6-tetrakisphosphate inhibits the calmodulin-dependent protein kinase II-activated chloride conductance in T84 colonic epithelial cells. J Biol Chem 271: 14092-14097, 1996. 